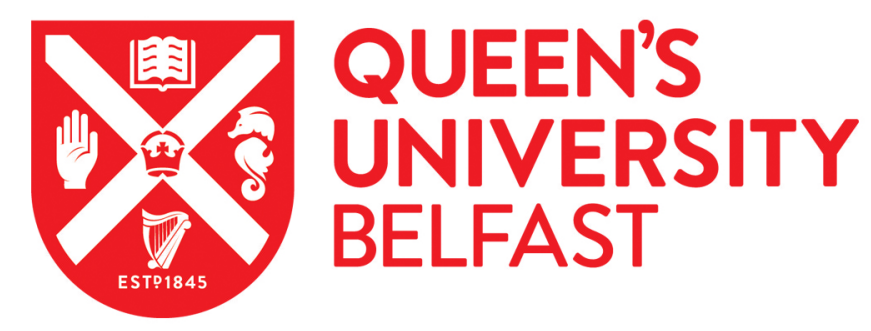

\title{
Experimental Study of Interfacial Stress Distribution of Bonded-in BFRP Rod Glulam Joints Using Fibre Optic Sensors (FOS)
}

Yeboah, D., Taylor, S., \& McPolin, D. (2016). Experimental Study of Interfacial Stress Distribution of Bonded-in BFRP Rod Glulam Joints Using Fibre Optic Sensors (FOS). Structures, 8(1), 53-62.

https://doi.org/10.1016/j.istruc.2016.08.006

\section{Published in:}

Structures

\section{Document Version:}

Peer reviewed version

Queen's University Belfast - Research Portal:

Link to publication record in Queen's University Belfast Research Portal

\section{Publisher rights}

(C) 2016 The Institution of Structural Engineers. Published by Elsevier Ltd. All rights reserved. This manuscript version is made available under the CC-BY-NC-ND 4.0 license http://creativecommons.org/licenses/by-nc-nd/4.0/,which permits distribution and reproduction for noncommercial purposes, provided the author and source are cited.

\section{General rights}

Copyright for the publications made accessible via the Queen's University Belfast Research Portal is retained by the author(s) and / or other copyright owners and it is a condition of accessing these publications that users recognise and abide by the legal requirements associated with these rights.

Take down policy

The Research Portal is Queen's institutional repository that provides access to Queen's research output. Every effort has been made to ensure that content in the Research Portal does not infringe any person's rights, or applicable UK laws. If you discover content in the Research Portal that you believe breaches copyright or violates any law, please contact openaccess@qub.ac.uk. 


\title{
Experimental study of interfacial stress distribution of bonded-in BFRP rod glulam joints using fibre optic sensors (FOS)
}

\author{
David Yeboah ${ }^{1}$, Su Taylor ${ }^{2}$, Danny McPolin ${ }^{3}$ \\ ${ }^{1}$ School of Energy, Construction and Environment, Coventry University. CV1 5FB. \\ ${ }^{2,3}$ School of Planning, Architecture and Civil Engineering. Queen’s University Belfast, BT9 5AG.
}

\section{INTRODUCTION}

An innovative technique to create moment connections using rods, such as, steel and fibre reinforced polymers (FRPs), loaded into structural timber elements is preferred over the mechanical connections. Some of the advantages achieved through bonded-in rod techniques include transfer of high localised forces, formation of stiff connections and good fire resistance properties, since the host timber acts as insulating material to the connections [1,2]. Other advantages are that, dissimilar materials can be bonded and shear stresses are uniformly transferred between materials [3]. Moreover, adhesive joint requires little or no damage to the adherends and is capable of resisting fatigue compared to the other jointing techniques [4]. Bonded-in rods have been successfully used for almost 30 years for repair and strengthening of timber structures [1,5].

Connections with bonded-in rods are of a hybrid type, comprising timber, adhesive and rod. Timber used for connections with bonded-in rod joints is softwood, hardwood or a composite product such as glued laminated timber (glulam), parallel strand lumber (PSL) and laminated veneer lumber ( $\mathrm{LVL}$ ). In practice, glulam members made from softwood are most commonly used as the host material, due to their superior strength and stiffness compared to the sawn timber. In most cases, steel rods (threaded and reinforced types) have been used as the medium through which load is transferred because of their availability coupled with wellestablished surface preparations [6]. In the past two decades, fibre reinforced polymers (FRPs) are being considered as an alternative connecting rod for applications in timber structures. Adhesives commonly used in practice for bonded-in rod connections are one-and two-component epoxies, polyurethane and resorcinol types [5].

\subsection{Aims and objectives}

The performance of bonded-in rod connections is governed, mainly, by stresses at the interface, which are in turn controlled by many factors. However, investigation of the stresses at the interfaces of the bonded-in rod connections is limited, mainly, owing to difficulty in measuring interfacial stresses. Research into the use of GFRPs and CFRPs materials as reinforcement in timber is much more frequently published, compared to BFRPs. Moreover, the use of fibre optic sensors for investigating the stress/strain behaviour in timber connections has not yet been reported. The current research investigated the distribution of interfacial stresses using fibre optic sensors (FOS) in order to understand the mechanisms governing the behaviour of the joint for structural analysis and design purposes. Pull-out tests of bonded-in BFRP rods loaded parallel and perpendicular to the grain were used in this study. The effect of bonded length and load-to-grain on interfacial stress distribution was also discussed and analysed.

\footnotetext{
${ }^{1}$ Corresponding author. Tel: + 442476395249; Mob. +447938912547; E-mail address: ab6936@coventry.ac.uk
} 


\subsection{Background and previous research}

\subsubsection{FRP-timber connections}

In civil engineering applications, FRPs have several advantages over conventional materials, including improved resistance to corrosion, significantly higher strength-to-weight ratio, easier and faster handling and installation. Other advantages include low heat transmission during fire outbreak, low transportation costs due to reduced weight and higher tensile strength $[7,8]$. FRPs consist of strong fibrous materials fixed in a polymeric matrix to achieve a stable form of composite end product, with the strength properties dictated by the behaviour of the fibres [1]. The FRP materials can be classified as Glass Fibre Reinforced Polymers (GFRP), Carbon Fibre Reinforced Polymers (CFRP), Aramid Fibre Reinforced Polymers (AFRP) and Basalt Fibre Reinforced Polymers (BFRP).

\begin{tabular}{|c|c|c|c|c|}
\hline Material & Density $\left(\mathrm{kg} / \mathrm{m}^{3}\right)$ & Tensile strength (MPa) & Elastic modulus (GPa) & Cost (Euro/m $\left.\mathbf{m}^{3}\right)$ \\
\hline BFRP & 2700 & 1000 & 90 & 14,000 \\
\hline CFRP & 1500 & 1600 & $120-300$ & 90,000 \\
\hline GFRP & 1800 & 850 & 46 & 11,500 \\
\hline
\end{tabular}

Table 1: Material properties of FRPs [9]

Carbon and aramid fibres have higher strength and stiffness properties than glass or basalt fibre but CFRP and AFRP are far more expensive than GFRP and BFRP [8,9]. Therefore, based on their availability and cost, GFRP and BFRP can be the most cost-effective to replace steel. Table 1 shows that, basalt has higher strength in tension and possesses more improved resistance to corrosion than the corresponding glass fibre [10].

Several opportunities exist for the application of FRP rods in timber structures for new buildings, bridges as well as rehabilitation of existing structures [8,11]. Lorenzis et al [7] conducted tests to investigate the influence of bonded length, surface configuration of the CFRP rod and direction of the wood fibres with respect to the longitudinal axis of the connection on the bond performance of specimens. They used the test results to model local bond-slip behaviour of the connections. Harvey and Ansell [10] investigated the use of GFRP as an alternative connecting rod in bonded-in rod joints. They fabricated and tested pull-out samples loaded with the GFRP rods in order to investigate the effect of rod surface preparation, bondline thickness, bonded length, type of adhesive, timber moisture content and timber type on the capacity of the connections. Raftery and Harte [12] investigated the reinforcement in bending of low-grade glulam with GFRP. They reported improvements in stiffness and ultimate bending moment when the reinforced glulam was compared with unreinforced ones. Experiments conducted to investigate the reinforcement of timber members with carbon FRP reinforcement have shown that the use of a small percentage of reinforcement resulted in increases in the flexural and stiffness capacities of up to $90 \%$ and $100 \%$ respectively [13-17]. Numerical model developed to predict the behaviour of clear timber beams reinforced with FRP showed that small amounts of FRP reinforcement resulted in increase in strength and stiffness of the beams $[18,19]$. Recently, an investigation into the use of basalt (BFRP) has also been conducted [20]. Basalt rods have been used as reinforced material in a concrete bridge deck (Thompson Bridge) in Co. Fermanagh, Northern Ireland [21]. 


\subsubsection{FRP-timber bond durability}

The moisture content of timber at the time of bonding represents one of the most important factors to take into consideration in the design of the bonded-in rod connections. The environment (humidity) in which the timber is located can change the moisture content and hence the strength of the member [22] due to the hygroscopic nature of timber. Moisture variations in timber can cause shrinkage and swelling which can result in considerable stresses as well as cracking. The stresses and the cracking together can result in reduction or loss of bond strength with bonded-in rods and therefore it is recommended to use these connections only in service classes 1 and 2 [23]

FRP composites are also known to show reduction in strength, thermo-physical, mechanical, and chemical properties upon exposure to water [24-26]. Moreover, an exposure of FRP composites to moisture can result in changing resin matrix, damaging fibre/matrix interface and fibre degradation [26]. However, the absorption of moisture (as a result of change in humidity) in FRPs is significantly lower, compared to that of timber [27]. GFRP composites exposed to hygrothermal ageing are known to decrease in tensile, compressive and shear strengths [28]. Chu and Karbhari [29] have reported that when GFRP is exposed to moisture for long time, the fibres are damaged through stress-corrosion mechanisms and cracking. An exposure of AFRP to moisture results in accelerated fibrillation [30]. Immersion of CFRP laminates in water at room temperature showed an initial decrease of $25-30 \%$ in tensile strength during first month of exposure, but remained constant during the rest of exposure period [31]. Wang et al [32] studied durability of basalt fibre and its epoxy resin composites in alkaline environments for 3 months. They reported that, the tensile strength of the BFRP reduced by $40 \%$, while the modulus was not affected. They observed that, the bare basalt fibre immersed in hygrothermal and alkaline environments showed a considerable degradation in the tensile properties, due to corrosion of the fibres. On the contrary, basalt fibre reinforcing bars show a much improved durability performance subjected to the same conditions.

Moisture in the adhesive can also considerably affect wetting, penetration and cure of the adhesives in the bond. However, for epoxy adhesives the above does not always occur [33,34]. An experiment conducted to investigate the adhesion between epoxy and some timber members at moisture content of $10 \%, 18 \%$ and $22 \%$ showed that the epoxy resins employed were able to bond the timber samples up to moisture content of up to $22 \%$ without any appreciable reduction in bond strength [33]. Temperature of the surroundings can affect the creep, fatigue and fire resistance of adhesive joints and therefore it can influence the durability of structural adhesive joints [4]. Epoxy adhesives perform best when kept below temperature of $50^{\circ} \mathrm{C}[35]$.

\subsubsection{Pull-out loading configurations}

In bonded-in rod connections, the main studies focus on tensile pull-out of samples and their dependency on the host timber and their adherends as well as other factors that influence the capacities of the bond [9]. There are four main types of loading configurations for pull-out tests, which are pull-pull, pull-compression, pull-beam and pull-pile foundation [5,6]. Pullpull and pull-compression conditions are used mainly for both parallel and perpendicular to the grain tests, whereas pull-pile foundation and pull-beam situations are suitable for perpendicular to the grain tests only. The pull-pull loading configuration is more practical and produces higher pull-out capacities than the pull-compression type [36,37]. Experimental results by Harvey et al [38] also demonstrated that the pull-pull loading conditions exhibited more uniform distribution of stress along the bonded length. However, it is more expensive since more materials and fabrication processes are needed. The pull-beam configuration is inefficient and therefore not practical for pull-out tests because large amount of timber members is required for fabrication. Moreover during loading, the timber beams are subjected to bending stresses. In the case of the pull-pile foundation, the tensile force in the rod is 
balanced by shear stresses in the timber. Excessive compression perpendicular to the grain caused by the reaction forces is normally avoided by four screws with thread over the entire length and four glued-in steel rods acting like a "'pile foundation'. Moreover, tensile failure of timber in the perpendicular to the grain direction is prevented [39]. However, the pull-pile foundation loading configuration would be very expensive as more rods would be needed for the fabrication of the samples. The pull-compression configuration is not practical and the pull-out load could be influenced by stresses in compression perpendicular to the grain in the area close to the application of the load $[6,39]$. However, the pull-compression loading condition is relatively cheaper and the fabrication process is easier.

\subsubsection{Failure mechanisms of bonded-in rod joints}

Failure modes mostly associated with bonded-in rods are localised shear failure (close to the bond), interfacial rod/adhesive failure, failure of the rod and splitting along the grain $[1,40]$.

The shear failure of timber close to the bond occurs when the shear capacity of the timber is exceeded [34,40,41]. Results of pull-out tests of bonded-in BFRP rod connections showed that, the most significant failure mode was shear failure of timber adjacent to the bond which was associated with plug of wood and pull-out of rods [42]. This type of failure results in optimal bond strength [34,41].

Failure at the adhesive rod/adhesive interface depends mainly on the type of adhesive use for the bonding. Pull-out tests conducted by Bainbridge et al [43] showed cohesive failure in phenol resorcinol formaldehyde (PRF) resins, while epoxy and polyurethane samples recorded timber shear failure. Broughton and Hutchinson [34] also reported failure at rod/adhesive interface for most samples at moisture contents above $22 \%$.

Failure of rod is due to the material failure or buckling of the rod, outside of the timber in case of compression loading [5]. This mode of failure can occur when the diameter of the rod is smaller (e.g. $8 \mathrm{~mm}$ ) and edge distance is large enough to avoid rupture of the timber close to the joint to enable the tensile capacity of the rod to be exceeded. Tensile failure of FRPs are mainly brittle while for steel rods, yielding is possible resulting in a more ductile failure mode [44].

Longitudinal timber splitting results in a tensile failure in the timber perpendicular to the grain as a result of low tensile strength perpendicular to grain and low edge distance [5,7]. Pull-out results of CFRP rods loaded parallel to the grain of timber specimens recorded longitudinal splitting at bonded lengths varying between 50 - $200 \mathrm{~mm}$ [7].

\subsubsection{Stress-strain behaviour of bonded-in rod connections}

The capacity of bonded-in rod joint depends on the shear strength of the interfacial layer of the samples [22,37], which is also governed by the mechanical and geometrical properties of the host timber, the connecting rod and the adhesive. For rods with outer deformations, the adhesive distributes the force along the axis between the ribs. In that case, the load is transferred by mechanical contact and adhesion [41]. In the case of sandblasted or graincovered rod surfaces (such as FRPs), the performance of the adhesive connection can be governed by adhesion and friction [45]. In situations where the diameter of the rod is very close to the diameter of the hole drilled through the host timber, the connections behave similarly to screw joint. In such situations, the load is transferred by the compressive behaviour between the wood and the shanks of the screw [37]. 


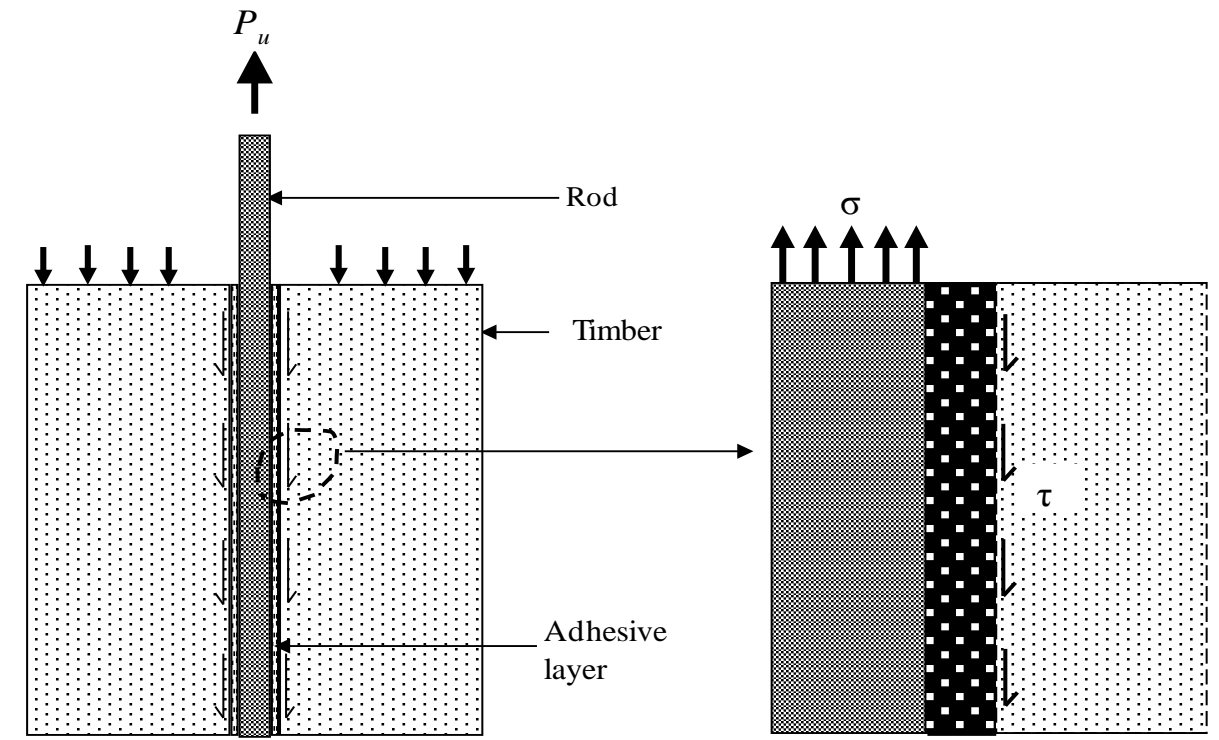

Figure 1: Load transfer in bonded-in rod joint [41]

Benasconi [41] used Figure 1 to illustrate the load transfer along the interface of a typical bonded-in rod connection and observed that, failure of the connection occurred at the timber/adhesive interface. According to Bernasconi [41], the value of the shear stress can be interpreted as the average shear stress acting along the adhesive layer. This theory assumes that, the interfacial stress distribution along the length of the rod is uniform.

However, in practice, the stress distribution of bonded-in rods is non-uniform [5] and this has been supported by [4], as shown in Figure 2.
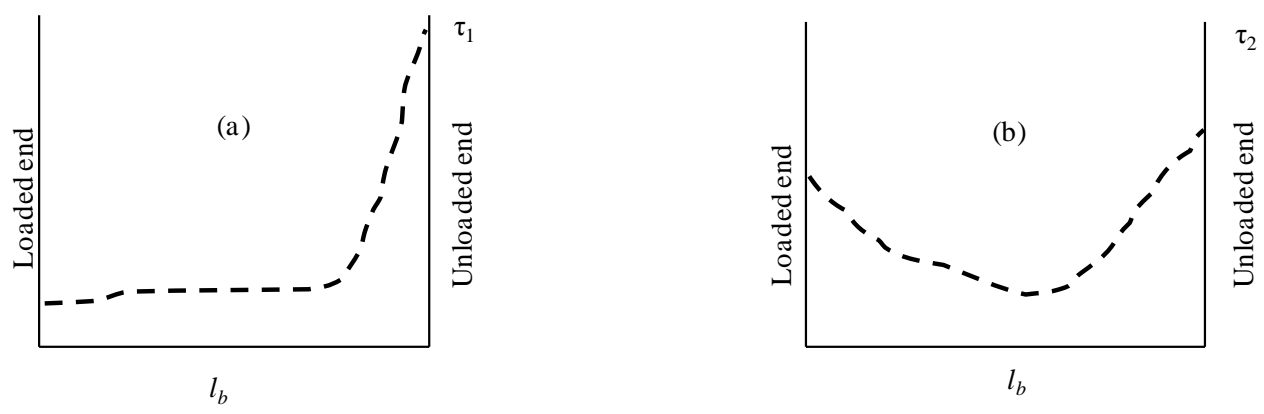

Figure 2: Theoretical shear stress distribution in a bonded-in rod connection at: (a) rod/adhesive interface and (b) at timber adhesive interface [4].

Finite element analysis has also been used by Deng et al [46] to study the mechanisms of load transfer and the stress distributions of bonded-in steel rods in glulam timber samples. They reported that, the shear stress distribution was not uniformly distributed along the bonded length of the timber samples. According to [46] the highest shear stress concentrations in the adhesive layer occurred at both ends of the bonded length and that the stress concentration at the unloaded end of the rods was higher than that of the outer end.

The results of [46 have been supported by [47], who also used pull-out samples of bonded-in steel rod joints to investigate interfacial stress distributions along the bonded length. Their results showed that, the highest stress concentration occurred at a point where the steel rods entered the opening of the host timber, which contradicts [4], shown in Figure 2. 


\section{MATERIALS AND METHODS}

\subsection{Materials}

Materials used for the experiment were glulam timber, 2-part epoxy gap-filling adhesives and 12 mm BFRP rods. Details of the properties of the materials are shown in Table 2.

\begin{tabular}{|c|c|c|c|c|c|}
\hline \multirow[b]{2}{*}{ Material } & \multicolumn{5}{|c|}{ Property } \\
\hline & $\begin{array}{c}\text { Tensile strength } \\
\left(\mathbf{N} / \mathbf{m m}^{2}\right)\end{array}$ & $\begin{array}{c}\text { Compressive } \\
\text { strength }\left(\mathbf{N} / \mathbf{m m}^{2}\right)\end{array}$ & $\begin{array}{l}\text { Bending strength } \\
\qquad\left(\mathrm{N} / \mathbf{m m}^{2}\right)\end{array}$ & $\begin{array}{c}\text { Shear strength } \\
\left(\mathbf{N} / \mathbf{m m}^{2}\right)\end{array}$ & $\begin{array}{l}\text { Modulus of Elasticity } \\
\qquad\left(\mathrm{N} / \mathbf{m m}^{2}\right)\end{array}$ \\
\hline Timber* & 19.5 & 42.2 & 56 & 11.9 & 12600 \\
\hline BFRP & 920 & - & - & - & 54000 \\
\hline Ероху** & 2800 & 68 & 70 & 12.5 & 3,700 \\
\hline
\end{tabular}

Table 2: Properties of the materials used for bonded-in BFRP rod specimens

**Properties of epoxy resins are from the manufacturer. *Timber samples were loaded in parallel to the grain direction

\subsubsection{Timber}

The timber blocks were cut from Spruce glulam elements (cross section dimension $90 \mathrm{~mm} \mathrm{x}$ $270 \mathrm{~mm}$ ) with strength class GL28. The compressive and tensile strengths determined were, $42.3 \mathrm{~N} / \mathrm{mm}^{2}$ and $44.4 \mathrm{~N} / \mathrm{mm}^{2}$, respectively, in accordance with [48]. The average density of the samples was $450 \mathrm{~kg} / \mathrm{m}^{3}$. Glulam was the host timber for this investigation because of its relatively uniform mechanical properties.

\subsubsection{Basalt bars}

Basalt fibre reinforced polymer connecting rods were adopted for the experiment due to their high strength, low weight, corrosion resistance and as a less expensive alternative to CFRP rods [49]. The diameter of the BFRP rods used was $12 \mathrm{~mm}$ due to its commercial availability.

\subsubsection{Epoxy adhesive}

The 2-part thixotropic epoxy gap filling, comprising the base and hardener, was used as the adhesive for the test because epoxy resin is an ideal resin for adhesive applications [50,51]. Epoxy adhesives do not require high pressure during their application and curing, and are reasonably tolerant with regard to bondline thickness variations. They also exhibit strong adhesion to several materials, little or no shrinkage during cure, dimensional stability after hardening, excellent mechanical resistance and high resistance to chemical products and water [52,53]. Shear capacity of epoxy resins is 2-3 times that of timber [50]. The glass transition temperature for the epoxy was below $50^{\circ} \mathrm{C}$ [Rotafix Ltd].

\subsection{Fabrication methods and test procedure}

In this section, fabrication or bonding of the timber samples with BFRP connecting rods and the epoxy adhesives are described. The bonding of the FOS on the BFRP rods also explained. This section also depicts testing of the pull-out samples.

\subsubsection{Fabrication of bonded-in BFRP timber samples}

Test variables used for the experiment are depicted in Table 3. One sample of each test configuration (for parallel and perpendicular to the grain samples) was bonded with FOS. Thus a total of eleven samples were bonded with FOS cables. The moisture content of the 
timber blocks determined by oven-drying method prior to bonding ranged from $8 \%$ to $10 \%$, which was suitable for bonding [48].

\begin{tabular}{|c|c|c|}
\hline \multicolumn{3}{|c|}{ Parallel to the grain samples } \\
\hline Test No. & Bonded length, $l_{b}(\mathrm{~mm})$ & No. of tests \\
\hline $\mathrm{P}_{\mathrm{Bl}}-100$ & 100 & 1 \\
\hline $\mathrm{P}_{\mathrm{Bl}-150}$ & 150 & 1 \\
\hline $\mathrm{P}_{\mathrm{Bl}}-200$ & 200 & 1 \\
\hline $\mathrm{P}_{\mathrm{Bl}}-250$ & 250 & 1 \\
\hline $\mathrm{P}_{\mathrm{Bl}-300}$ & 300 & 1 \\
\hline $\mathrm{P}_{\mathrm{Bl}}-350$ & 350 & 1 \\
\hline \multicolumn{3}{|c|}{ Perpendicular to the grain samples } \\
\hline Test No. & No. of tests & Bonded length, $l_{b}(\mathrm{~mm})$ \\
\hline $\mathrm{P}_{\mathrm{Bd}}-100$ & 100 & 1 \\
\hline $\mathrm{P}_{\mathrm{Bd}}-150$ & 150 & 1 \\
\hline $\mathrm{P}_{\mathrm{Bd}}-200$ & 200 & 1 \\
\hline $\mathrm{P}_{\mathrm{Bd}}-250$ & 250 & 1 \\
\hline $\mathrm{P}_{\mathrm{Bd}}-270$ & 270 & 1 \\
\hline
\end{tabular}

Table 3: Test variables used for the pull-out tests

Notation: $\mathrm{P}_{\mathrm{Bl}}-100-\mathrm{P}=$ Pull-out; $\mathrm{B}=\mathrm{BFRP}$ rod; $\mathrm{l}=$ parallel to the grain; $100=$ bonded length. $\mathrm{P}_{\mathrm{Bd}}-100-\mathrm{P}=$ Pull-out; $\mathrm{B}=\mathrm{BFRP}$ rod; $\mathrm{l}=$ perpendicular to the grain; $100=$ bonded length

In each timber specimen, a $16 \mathrm{~mm}$ diameter hole, (in accordance with bonded lengths shown in Table 3) was machined through the specimen. As a result, the gap between the BFRP and the timber was $2 \mathrm{~mm}$, which gives the minimum glueline thickness for optimum bond capacity [8]. Prior to bonding, epoxy resins were used to coat the end of each rod to which the pull-out load had to be applied in order to enhance gripping. The rods were located centrally in the hole by means of a locator point. The specimens were fabricated by inserting the BFRP rods into the drilled holes which have been partially filled with the epoxy resins. Before testing, the fabricated specimens were allowed to cure for six (6) at temperature of $20^{\circ} \mathrm{C}$.

\subsubsection{Bonding Fibre Optic Sensors (FOS) on the BFRP rods}

Prior to fabrication, Fibre Optic Sensors (FOS), with Bragg gratings (FBG) of $1 \mu \mathrm{m}$ modulation, were fixed spatially along the BFRP (see Figures 3 and 4) of the nine samples to detect strains along the BFRP rods within the bonded length. The sensors (FOS) were used for this experiment due to their flexibility. They are also excellent for measuring strains in small spaces such as interfaces (the bar/adhesive interface). 


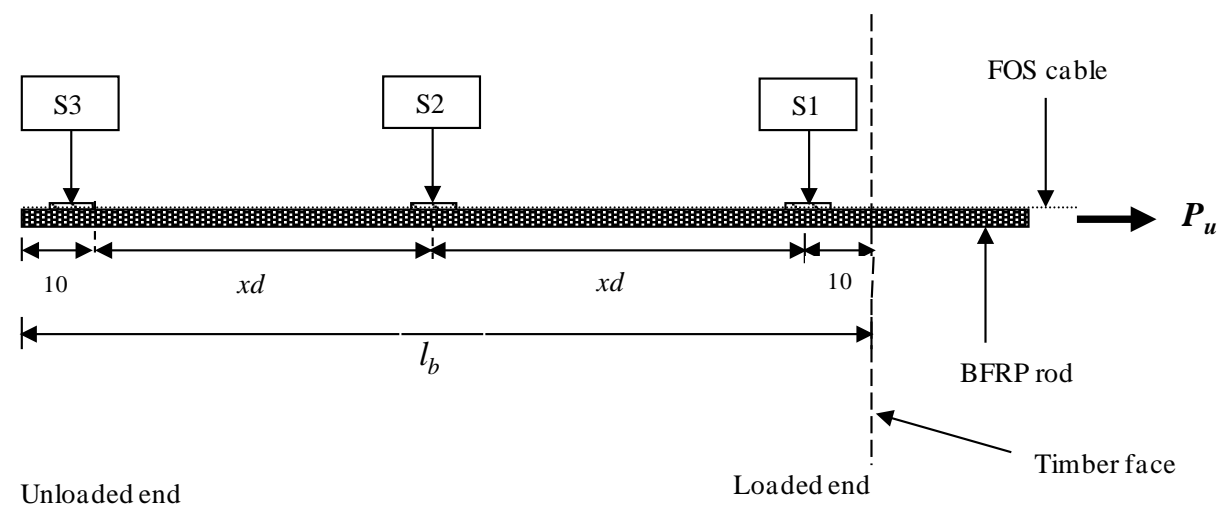

Figure 3: Fibre Optic Sensors positioned on the BFRP rod.

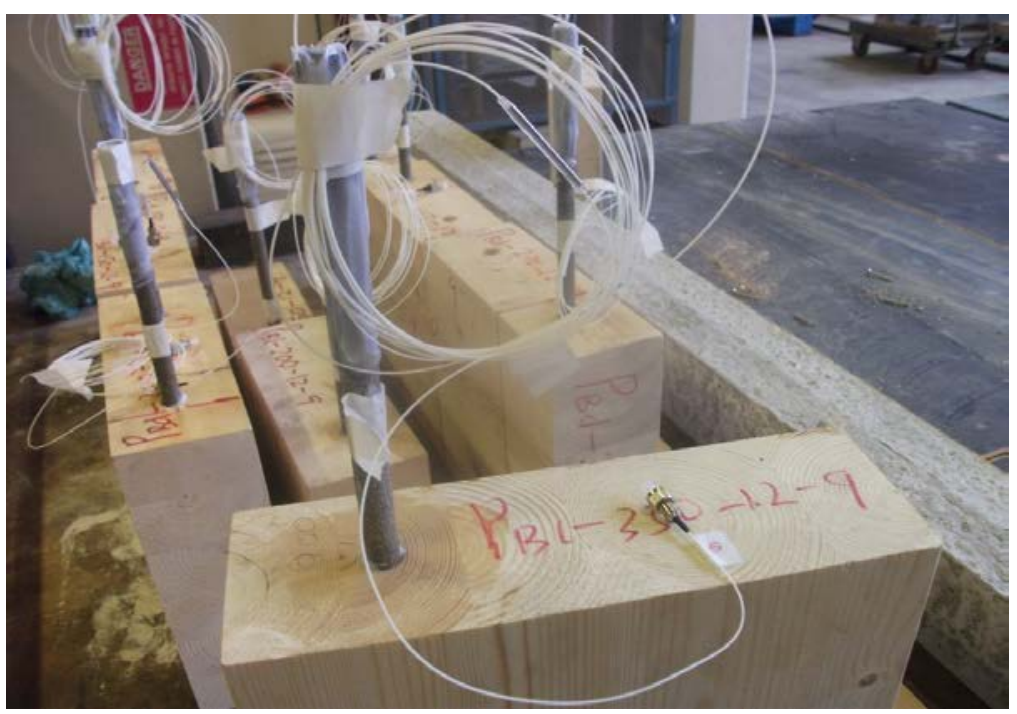

Figure 4: Samples bonded with Fibre Optic Sensors.
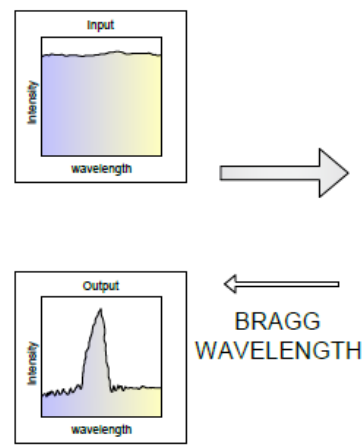
WAVELENGTH

\section{FBG}

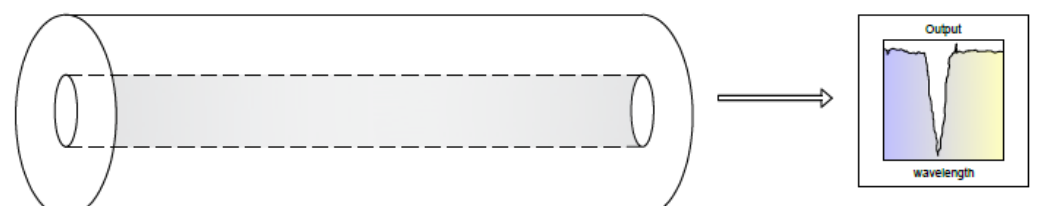

Figure 5: Functional principle of FBG [55].

Moreover, the discrete size of the cables meant minimal interference to the bond behaviour, unlike the more bulky vibrating wire strain gauge technologies [54,55].

Fibre Bragg Grating (FBG) sensors (Figure 5) are regarded as the major leading technology and the most mature grating-based sensors which are being used for monitoring crack and damages in structures. The sensors reflect a portion of the incoming light of a particular wavelength, which is called Bragg wavelength, and leaves the rest of the incoming light 
without changing its property. The Bragg wavelength is defined by the fibre refractive index and grating pitch and it is affected by change in temperature, strain, vibration and other parameters. These environmental changes are then reflected on the Bragg wavelength shift. Hence, many measurands, such as strain, can be measured by monitoring the Bragg wavelength shift of the FBG sensors [55].

For each sample configurations (parallel and perpendicular to the grain specimens), three FOS, each of diameter $0.2 \mathrm{~mm}$, were bonded at pre-determined positions of the BFRP rods. Thus, one sample of each test configuration was bonded by the FOS due to economic reasons. The reference point for the tests was the FOS at the top of the rod (loaded-end). In order to monitor the strain distribution along the BFRP rods, the first sensor (S1) was positioned 10 $\mathrm{mm}$ from the loaded end and another one (S2) at the middle of the rod and the third sensor (S3) $10 \mathrm{~mm}$ from the unloaded-end of the rod. The distance $x d$ between the sensors was calculated as $\left(l_{b}-20\right) / 2 \mathrm{~mm}$.

\subsubsection{Test procedure}

The testing of the bonded-in BFRP rod connections involved determination of the capacity of the bond, measurements of interfacial strains and the bond slip.

\subsubsection{Pull-out testing}

The loading configuration for the current experiment was pull-compression type (Figure 6) which was considered as the most suitable means of investigating the bond strength of the bonded-in rod timber samples due to economy performance and bonding process. The BFRP specimens were tested at temperature of $20^{\circ} \mathrm{C}$ which was considered appropriate for joints with epoxy resins [34].

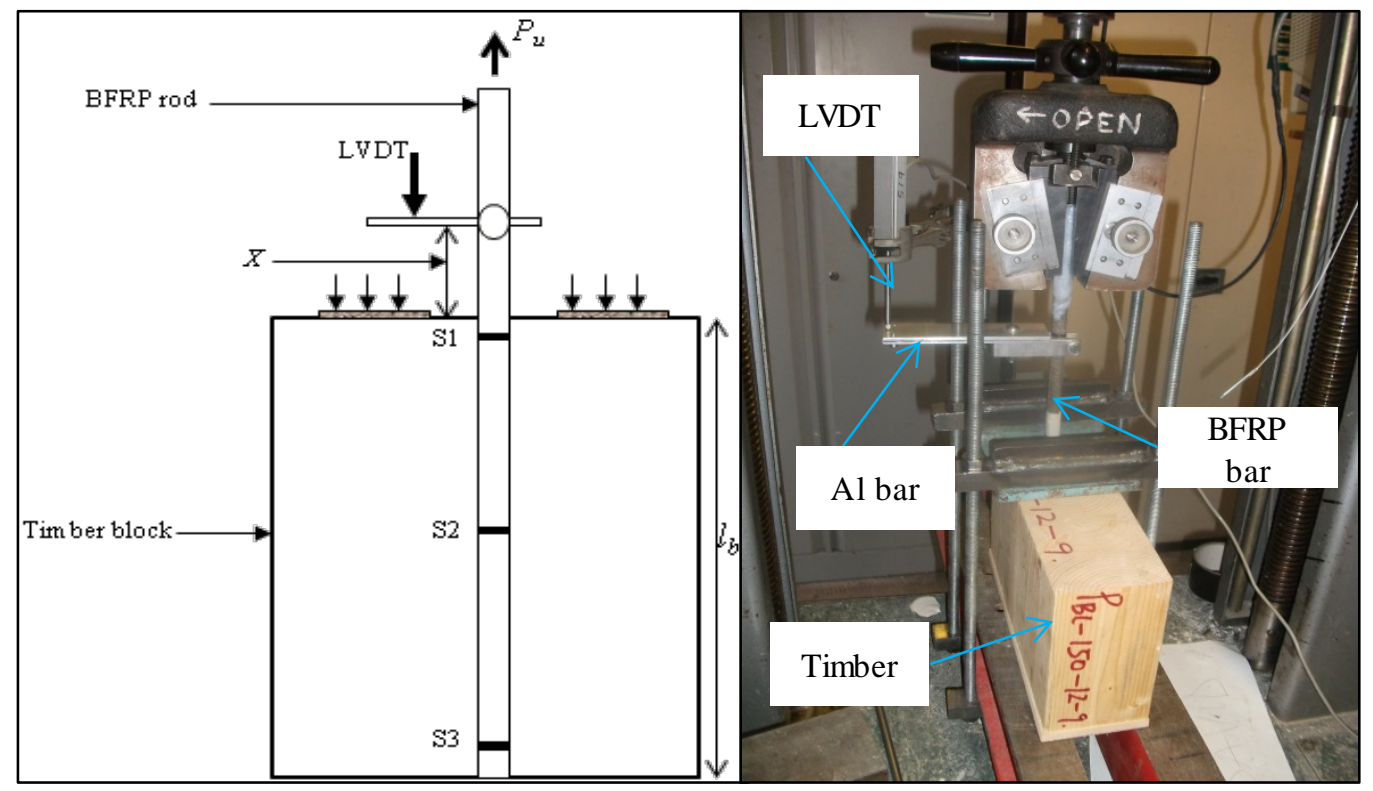

Figure 6: Test set up and instrumentation.

The samples were loaded incrementally to failure by applying the load in tension, as shown in Figure 6. During loading the square base plate together with the two T-section arrangements, provided compression against the specimens as the BFRP rods was pulled through the pullthrough hole (of the base plate) at a constant cross-head displacement of $3 \mathrm{~mm} / \mathrm{min}$ in accordance with BS EN: 26891 [56]. The maximum load for each sample configuration was recorded when there was total separation of the bond with accompanied zero load-bearing capacity. All data was converted into Excel format for processing and analysis at the conclusion of the tests. 


\subsubsection{Interfacial strain and bond slip measurement}

For the measurement of bond slip and strain, an initial reference reading was taken from both sensor and LVDT at zero prior to a load being applied on the respective samples. In order to compare the load and the strain data from the system, a time stamp was used. The tensile test machine did not have a load output, which could be compatible with the FOS acquisition systems.

The bond slip or the movement of the BFRP rod was measured by Linear Variable Differential Transformer (LVDT) attached to the BFRP rods. The time for a particular predetermined load was known. The LVDT was fixed at a distance, $X$, (see Figure 6 ) at the loaded end of the bonded length by means of an aluminium bar which was attached to the tested BFRP rod. In order to measure the bond slip, the elongation of $X$ was subtracted from the total reading from the LVDT. Since the test machine did not have an output that allowed the load to be recorded automatically, readings from the LVDT were taken at predetermined hand written load figures ( $3 \mathrm{kN}$ intervals). This was done by controlling the speed and direction of the load applied, reducing speed to zero, thus holding the test machine load steady, at the appropriate predetermined loads. The trigger for taking these readings was an external switch connected to the data logger which when closed caused the logger to record the voltage from the LVDT at that exact time and date. Moreover, the tests in connection with the FOS were run parallel with the LVDT. A scanning rate of $1 \mathrm{~Hz}$ was used for the FOS and the average over 10 seconds was used in the results to match the scanning rate for the LVDT. Therefore, the corresponding load when the strain was taken was simply deduced by comparing these two parameters.

\section{RESULTS AND DISCUSSION}

The perpendicular and parallel to the grain results (including failure mechanisms, the relationship between load and bonded length), have been previously published in [20] and [57] respectively. The present paper presents the original results in relation to interfacial strain measurement with discrete optical sensors (FOS). The bond slip behaviour of the specimens is also presented and discussed.

Pull-out performance of the FOS samples is illustrated in Table 4. Figures 7-11 show the distribution of strain at the interfacial zone. The cables of the sensors (FOS) failed at $24 \mathrm{kN}$ and $15 \mathrm{kN}$ for parallel and perpendicular to the grain specimens respectively. Hence, the stress-strain graphs of the bonded specimens were limited to $24 \mathrm{kN}$ and $15 \mathrm{kN}$ respectively. Figure 12 also shows comparison of bond stress-slip behaviour for parallel and perpendicular to the grain samples.

During bonding, the FOS cables for the $100 \mathrm{~mm}$ and $200 \mathrm{~mm}$ pull-out samples (both parallel and perpendicular configurations) failed and therefore they were not included in the experimental results.

\subsection{Bonded length versus interfacial strain of the samples}

In this section, the stress-strain behaviour of the samples (at the predetermined positions along the rod at the rod/adhesive interface) is discussed. The influence of bonded length and load-to-grain on the distribution of the interfacial shear stress of the specimens is investigated.

\subsubsection{Stress-strain behaviour of parallel to the grain samples}

The results for the parallel to the grain samples (Figure 7) show that the sensors at the unloaded end and at the middle of the rod/adhesive interfacial, generally, recorded linear or uniform strains. The loaded end of the BFRP rod showed non-linear behaviour at the early stages of the loading and then tended to exhibit almost linear shape at an increasing loading. 
It was also noticed that the loaded end recorded the highest stress whereas the lowest stress occurred at the unloaded end of the BFRP rods. Thus, failure of the bond was more likely to occur at the loaded end than at the unloaded end.
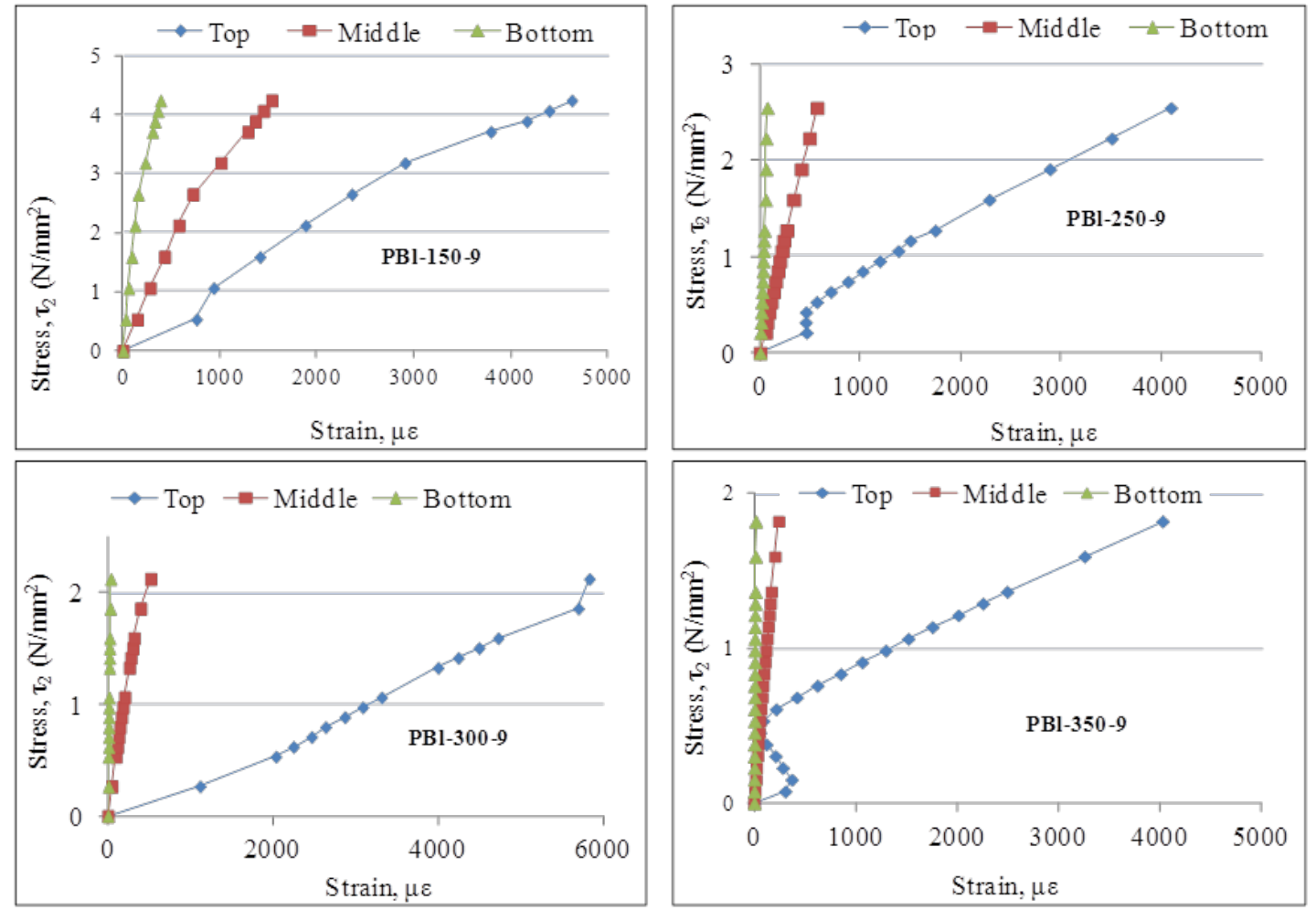

Figure 7: Effect of bonded length on the interfacial strain for parallel to the grain samples at an applied load of $24 \mathrm{kN}$.

\begin{tabular}{|c|c|c|c|c|}
\hline \multicolumn{5}{|c|}{ Parallel to the grain samples } \\
\hline \multirow{2}{*}{ Bonded length, $l_{b}(\mathrm{~mm})$} & FOS Samples & \multicolumn{3}{|c|}{ Average of 8 Samples } \\
\hline & Pull-out load, $P_{u}(\mathrm{kN})$ & Pull-out load, $P_{u}(\mathrm{kN})$ & Sdev & $\mathrm{CoV}(\%)$ \\
\hline 150 & 37.9 & 37 & 4.2 & 11.3 \\
\hline 250 & 49.4 & 55 & 6.3 & 11.4 \\
\hline 300 & 47.2 & 54 & 5.1 & 9.4 \\
\hline 350 & 52.7 & 54 & 5.1 & 9.4 \\
\hline \multicolumn{5}{|c|}{ Perpendicular to the grain samples } \\
\hline \multirow{2}{*}{ Bonded length, $l_{b}(\mathrm{~mm})$} & FOS Samples & \multicolumn{3}{|c|}{ Average of 8 Samples } \\
\hline & Pull-out load, $P_{u}(\mathrm{kN})$ & Pull-out load, $P_{u}(\mathrm{kN})$ & Sdev & $\mathrm{CoV}(\%)$ \\
\hline 150 & 52.2 & 49 & 2.8 & 5.6 \\
\hline 250 & 59.2 & 58 & 3.9 & 5.1 \\
\hline 270 & 66.0 & 56 & 4.6 & 9.2 \\
\hline
\end{tabular}

Table 4: Pull-out results of samples tested with FOS 
The stress-strain relationship of the specimens loaded parallel to the grain (Figure 7) showed that increasing the bonded length resulted in corresponding decrease in the stress at the unloaded end (S3). Thus, it was easier to debond samples with shorter bonded lengths. Moreover, the sensor at the top of the rod recorded more significant strain values as compared to that at the bottom of the rod. At the unloaded end of the samples with $150 \mathrm{~mm}$ bonded length, the FOS recorded higher strain values compared to the corresponding higher bonded lengths (Figure 8). In the case of the $250 \mathrm{~mm}$ to $350 \mathrm{~mm}$ bonded length samples, there was no significant change in the strain at the unloaded end of the BFRP rod. Thus it is noticed that the stress did not significantly change the stiffness at the interfaces when the bonded length was $250 \mathrm{~mm}$ and beyond.

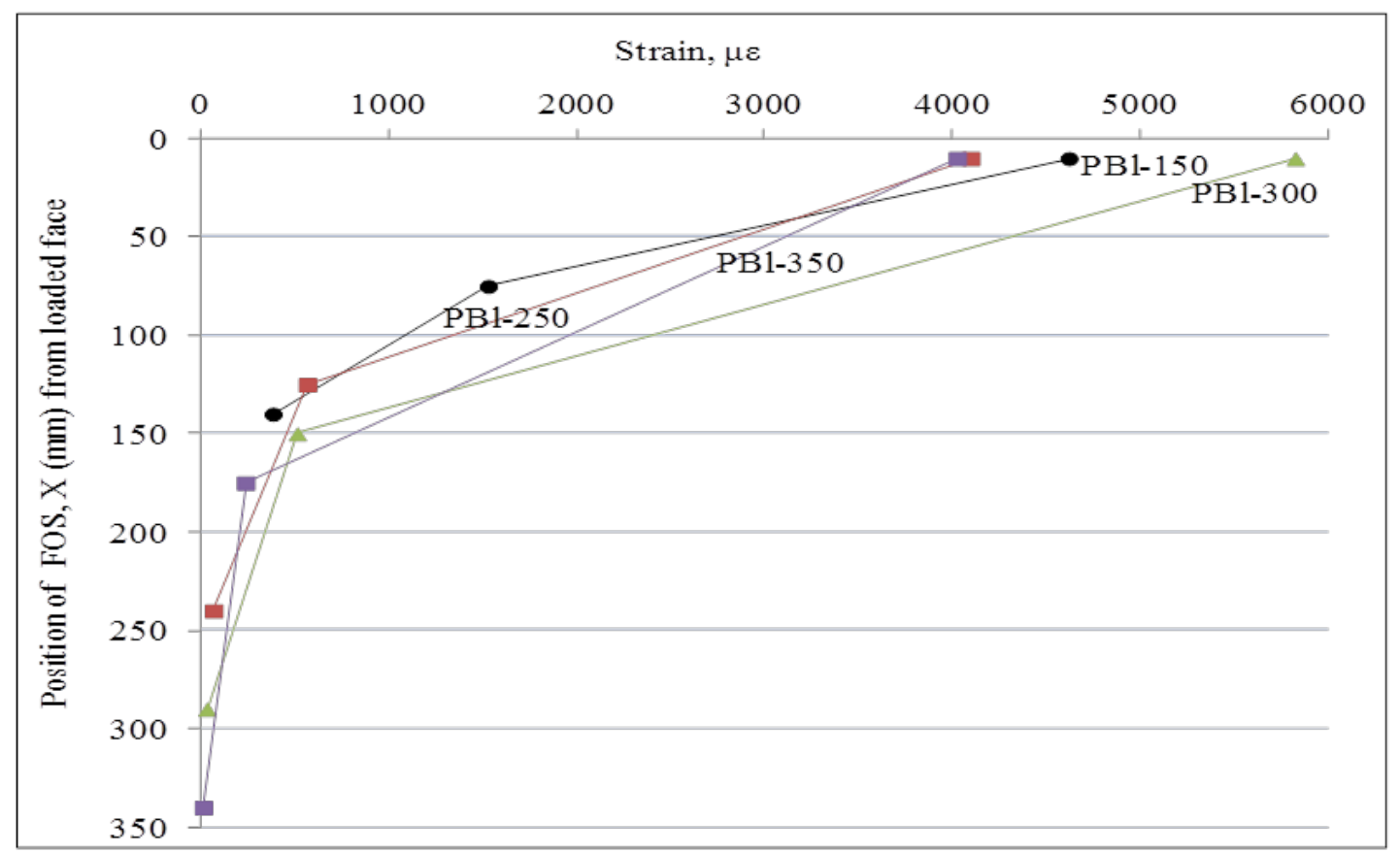

Figure 8: Strain at an applied load of $24 \mathrm{kN}$ for parallel to the grain samples.

The pull-out capacity of the specimens shown in Table 4 indicated that, the bond strength of the samples reached maximum at $250 \mathrm{~mm}$. Beyond $250 \mathrm{~mm}$ bonded length, the average pullout load remained almost unchanged, indicating that for design of $12 \mathrm{~mm}$ BFRP rod loaded parallel to the glulam members, the design bonded length was $250 \mathrm{~mm}$.

\subsubsection{Stress-strain behaviour of perpendicular to the grain samples}

Figure 9 shows that the stress-strain behaviour of the perpendicular to the grain samples was similar to those of the parallel to the grain samples. The highest strain was recorded at the loaded end of the samples whilst unloaded end of the BFRP rod recorded the lowest strain. The results also show that, as the volume of the epoxy in the length of the drilled hole increased, the strain increased at the loaded end of the samples.

The results showed that, at the unloaded end of the $250 \mathrm{~mm}$ and $270 \mathrm{~mm}$ bonded length samples, there was no significant deformation at an applied load of $15 \mathrm{kN}$. In the case of 100 $\mathrm{mm}$ and $150 \mathrm{~mm}$ samples, the interfacial strain was almost $3 \mathrm{~N} / \mathrm{mm}^{2}$. It is noticed that during loading, the $250 \mathrm{~mm}$ and $270 \mathrm{~mm}$ specimens allowed deformation at the loaded end of the rod, while at the same time firmly grasping the unloaded end of the specimen down (Figure 10 ), resulting in higher bond strength. The pull-out capacity of the perpendicular to the grain samples depended on the value of the peak interfacial stresses at the loaded end of the specimens. 

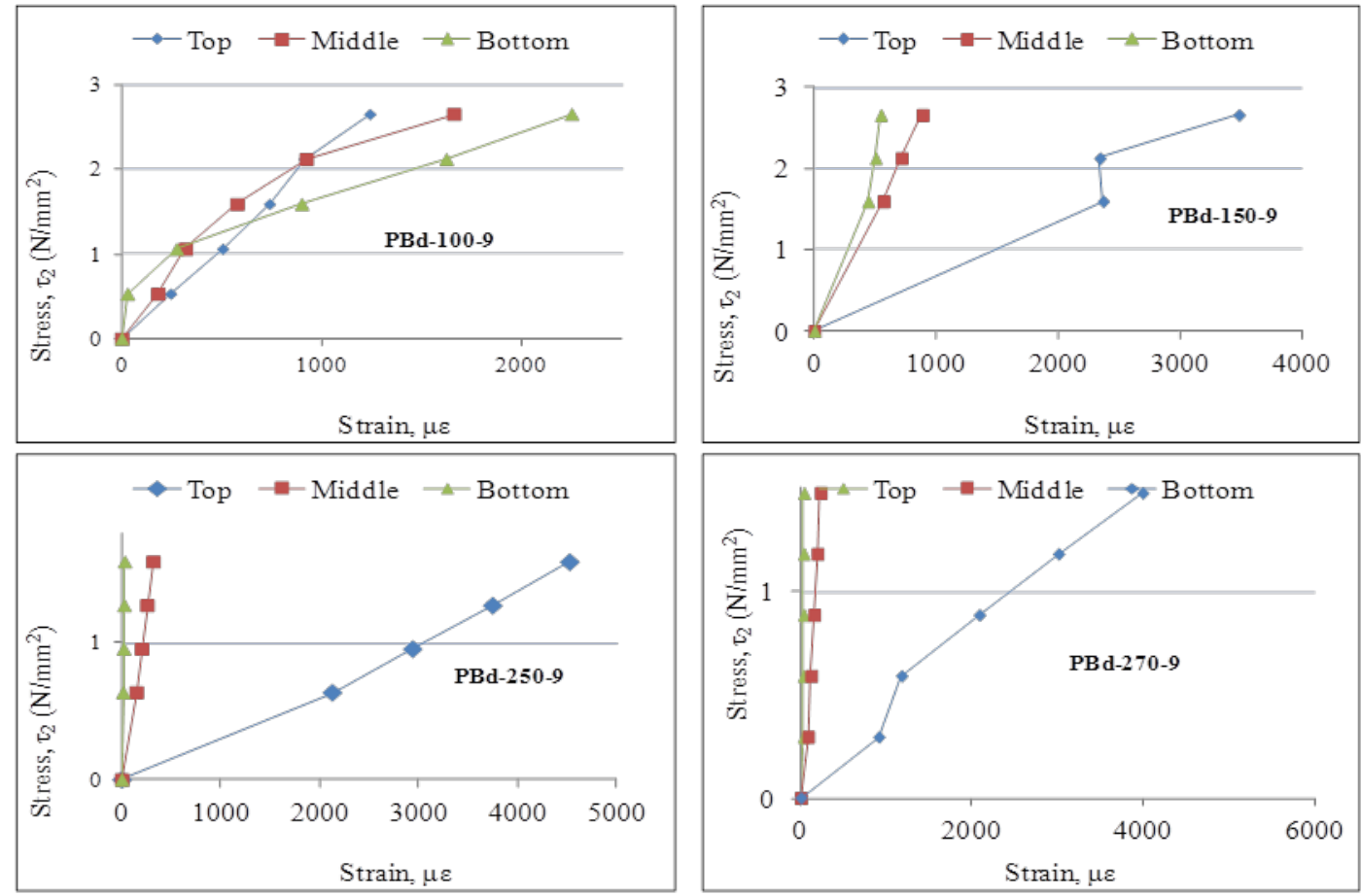

Figure 9: Effect of bonded length on the interfacial strain for perpendicular to the grain samples at an applied load of $15 \mathrm{kN}$.

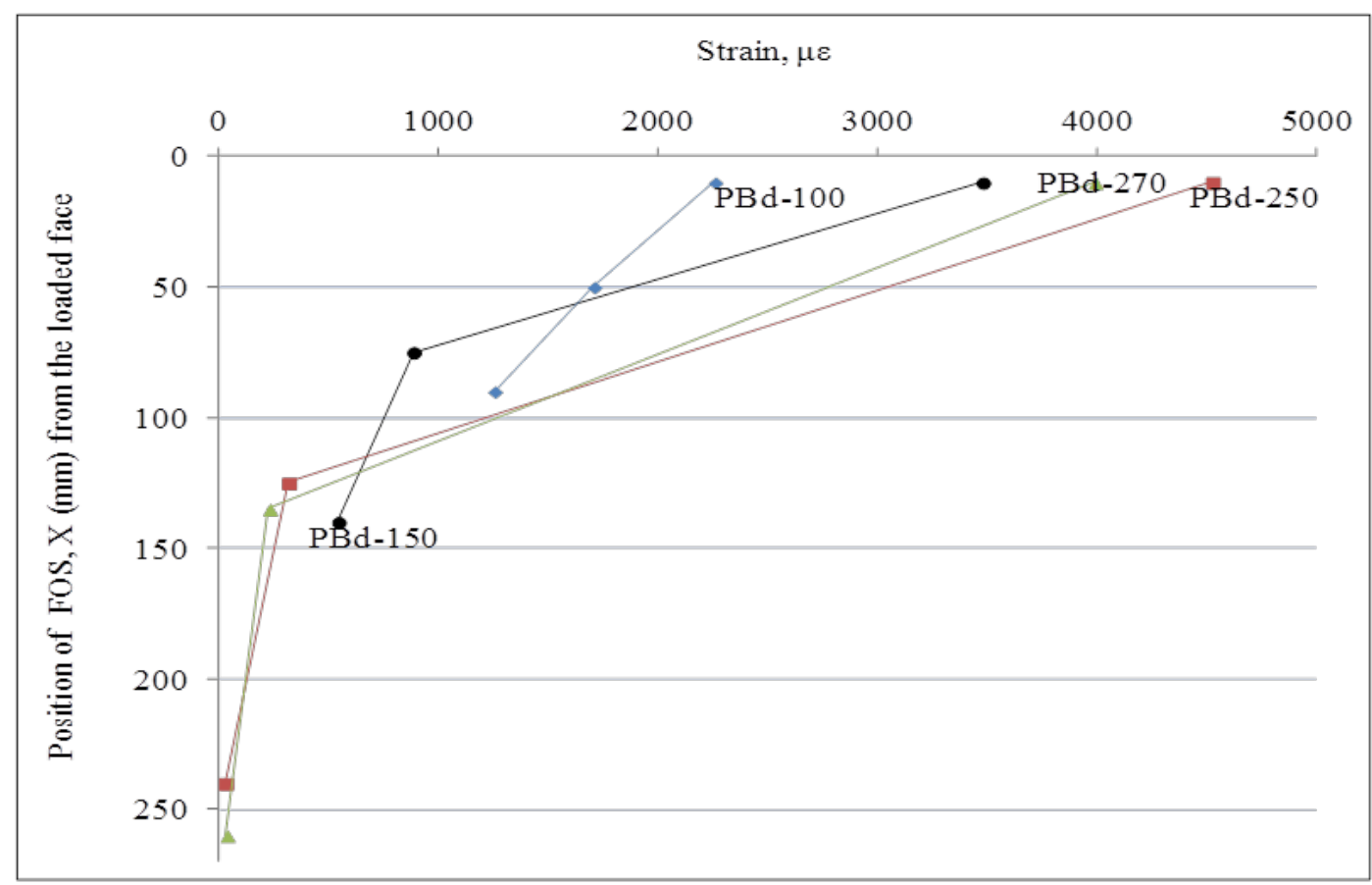

Figure 10: Strain at an applied load of $15 \mathrm{kN}$ for perpendicular to the grain sample.

The above investigations (for parallel and perpendicular to the grain samples) contradict earlier work by Deng et al [46] and Senno et al [47] who showed that interfacial stress concentration along the bonded length of bonded-in steel rod connections was highest at both ends of the bonded lengths and that the stress (strain) at the unloaded end of the steel bar was the highest. 


\subsubsection{Comparison of stress-strain behaviour of parallel and perpendicular to the grain samples}

It is observed in Figure 11 that, the peak strain at the loaded ends of both parallel and perpendicular to the grain was significantly higher than at the unloaded ends of the samples. That is, shear failure close to the adhesive layer or interface occurred more at the loaded end of the timber than at the unloaded end. In the case of $150 \mathrm{~mm}$ and $250 \mathrm{~mm}$ BFRP rods loaded perpendicular to the grain samples, the strain was $48 \%$ and $98 \%$ respectively higher than those of the corresponding parallel to the grain samples.

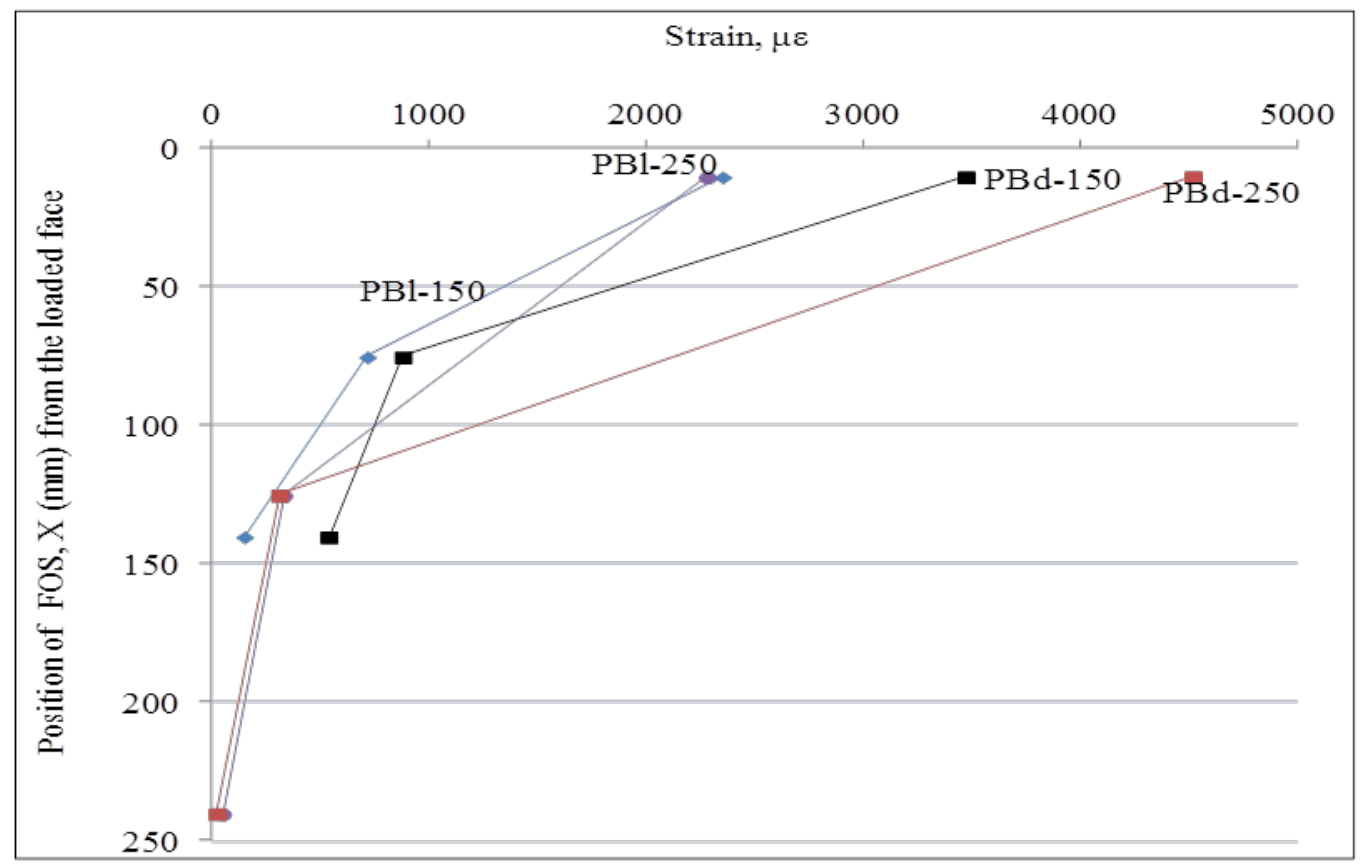

Figure 11: Comparison of strain up to $15 \mathrm{kN}$ for parallel and perpendicular to the grain samples.

The deformation at the unloaded end of the $150 \mathrm{~mm}$ sample bonded parallel to the grain was significantly lower than in the case of the perpendicular to the grain. There was no significant difference in the strain of the $250 \mathrm{~mm}$ samples bonded parallel and perpendicular to the grain. From these results, it was expected that the pull-out capacity of the parallel to the grain samples would be higher than the corresponding perpendicular to the grain samples. However, the pull-out results in Table 4 showed that the perpendicular to the grain samples recorded higher load capacity than the corresponding parallel to the grain samples. The higher stresses recorded for perpendicular samples were expected since timber is weak in the perpendicular to the grain direction as opposed to the direction which is parallel to the grain.

The holes drilled through the perpendicular to the grain members resulted in significant stress concentration as its depth increased. The higher stress concentration at the loaded end of the perpendicular to the grain samples may also be due to crushing of wood samples which was caused by compressive stress perpendicular to the grain when the metal plate was placed on top of the glulam timber blocks during loading. The perpendicular to the grain samples showed some pseudo-ductile behaviour and reserved more capacity to carry further load, provided the end grain distance was enough to resist splitting along the grain. The interfacial shear failure of the perpendicular to the grain samples was gradual involving crushing of the cell walls, whereas the samples loaded parallel to the grain exhibited brittle splitting behaviour.

\subsection{Bond stress-slip behaviour of the specimens}


The relationship between the interfacial stress and slip at loaded-end of the samples is illustrated in Figure 12. The results of bond stress-slip of the pull-out samples showed that perpendicular to the grain specimens exhibited significantly higher shear stress than the corresponding parallel to the grain samples. It was also observed that, samples loaded parallel to the grain exhibited brittle behaviour whereas the stress-slip response of the perpendicular to the grain samples less brittle behaviour. The difference in ductility of the samples was due to orientation of cells of the timber samples. In the parallel to the grain direction of timber, cells are arranged longitudinally which are boarded by brittle cell walls and hence failure was by separation of cells which is very sudden (brittle). Contrary to the parallel to the grain samples, the loading of perpendicular to the grain samples involved crushing of the cells which was gradual and resulting in reduction in brittleness.

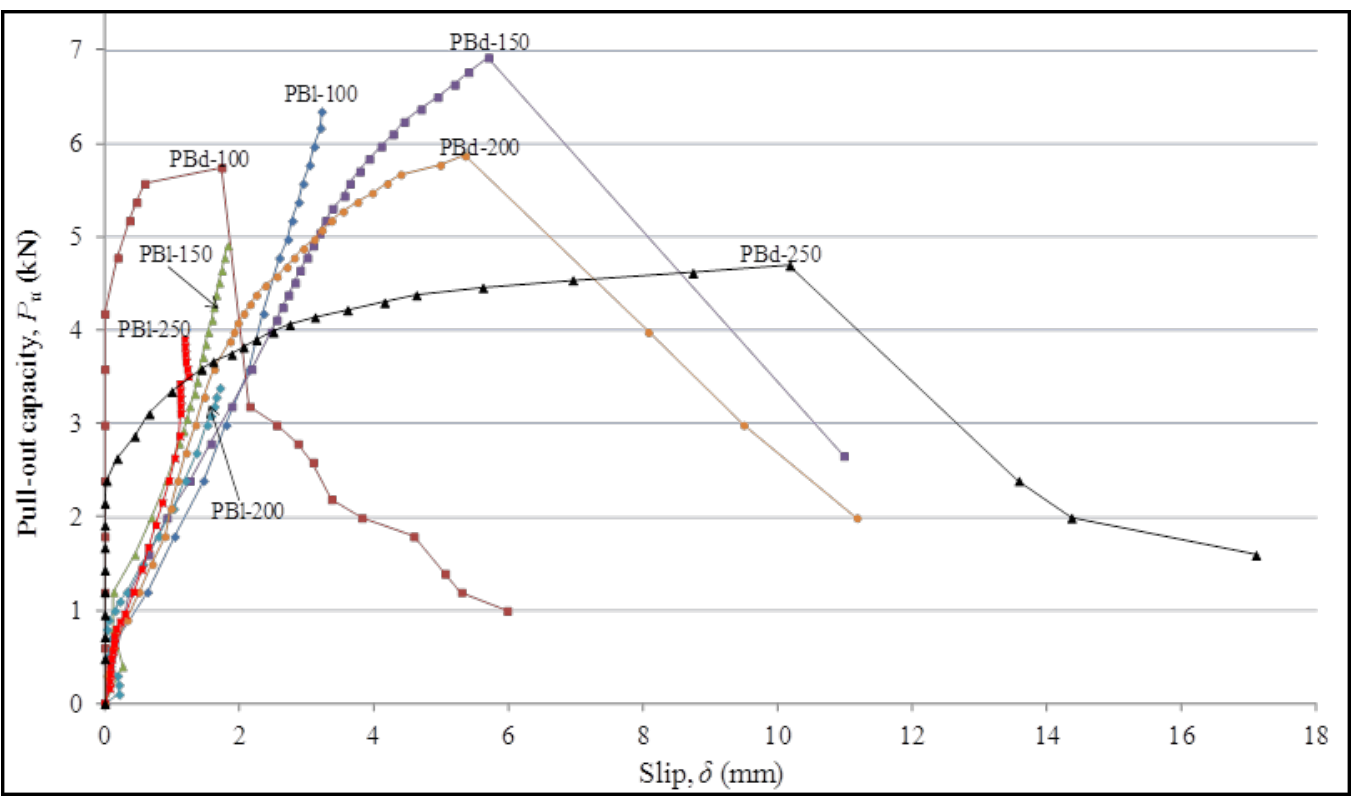

Figure 12: Bond stress-slip behaviour of samples loaded parallel and perpendicular to the grain.

For parallel to the grain specimens, the $250 \mathrm{~mm}$ samples exhibited very high stiffness and irregularity which could be due to improper monitoring of the LVDT computer controlled system. In the case of the $200 \mathrm{~mm}$ specimen, the epoxy glue at the grip of the machine debonded so the sample failed prematurely. In general, the samples loaded parallel to the grain were characterised by non-linear behaviour before the maximum value. This behaviour might be due to friction and defects in the timber specimens [7]. The specimens bonded perpendicular to the grain exhibited more uniform behaviour than the corresponding parallel to the grain samples.

\section{CONCLUSIONS}

Bonded-in rod connection is an innovative and efficient technique in strengthening timber members. The performance of this innovative tool is governed by stresses at the interfaces. The current research used fibre optic sensors to study the interfacial stress-strain behaviour of bonded-in BFRP rod glulam connections. It was found that, the interfacial stresses at the loaded end were higher than those at the unloaded end.

It was also observed that, samples loaded perpendicular to the grain increased in interfacial stress when the bonded length increased. In the case of the parallel to the grain samples, increasing bonded length at the same loading configuration resulted in decrease in interfacial stress at the loaded end. 
At the same loading configuration, the perpendicular to the grain samples recorded higher strain values than the corresponding parallel to the grain samples at the loaded end.

Moreover, the stress-slip behaviour of samples loaded perpendicular to the grain exhibited pseudo-ductile behaviour whereas the corresponding parallel to the grain samples showed non-linear response with brittle behaviour.

\section{ACKNOWLEDGEMENTS}

The authors would like to thank Queen's University, Belfast for supporting this project and also Magmatech Ltd for supplying the BFRP rods.

\section{REFERENCES}

[1] Mettem CJ, Bainbridge RJ, Broughton JG, Hutchinson A. Evaluation of Material combinations for bonded-in rods to achieve improved timber connections. CIB-W18 Meeting Thirty-two, Graz Austria; 1999, pp 1-13.

[2] Ansell MP, Madhoushi M. Behaviour of timber connections using glued-in GFRP rods under fatigue loading. Part II: Moment-resisting connections. Composites: Part B 39; 2008, p.249-257.

[3] Adams RD, Comyn J, Wake WC. Structural adhesive joints in Engineering. $2^{\text {nd }}$ Ed. Berlin: Springer; 1997.

[4] Custódio J, Broughton J, Cruz H. A review of factors influencing the durability of structural bonded timber joints. International journal of adhesion and adhesives. Elsevier publications; 2009, p.1-12.

[5] Serrano E, Steiger R, Lavisci P. Glued-in rods. In: Bonding of timber-core document of the COST Action E34'. Lignovisionen, 18; 2008, p. 31-39.

[6] Tlustochowicz G, Serrano E, Steiger R. State-of-the-art on timber connections with steel rods. Journal of Materials and Structures; 44(5); 2010, p. 997-1020.

[7] De Lorenzis L, Scialpi V, La Tegola A. Analytical and experimental study on bonded-in CFRP bars in glulam timber. Composites Part B: Engineering 36; 2005, p. 279-289.

[8] Micelli PEF, Vicenza SPE, La Tegola A. Flexural reinforcement of glulam timber beams and joints with carbon fobre-reinforced polymer rods. Journal of Composites for Construction; 2005, p. 337 -343.

[9] Steiger R, Serrano E, Stepinac M, Rajcic V, O’Neill C, McPolin D, Widmann R. Strengthening of timber with glued-in rods. Journal of Construction and Building Materials; 2015.

[10] Gentile C, Svecova D, Rizkalla S. Timber beams strengthened with GFRP bars: Development and applications. Journal of Composites for constructions; 2002, p. 12-20.

[11] Harvey K, Ansell MP. Improved timber connections using bonded-in GFRP rods. Proc. of $6^{\text {th }}$ WCTE World Conf. in Timber Eng., Whistler, Canada, 2001, p. 2-8.

[12] Harte AM, Raftery GM. Low-grade glued laminated timber reinforced with FRP plate. Composites: Part B 42; 2011, p. 724-735.

[13] Johns KC, Lacroix S. Composite reinforcement of timber in bending. Canadian Journal of Civil Engineering, Vol. 27; 2000, pp 899-906.

[14] Li YF, Xie YM, Tsai MJ. Enhancement of the flexural performance of retrofitted wood beams using CFRP composite sheets. Journal of Construction and Building Materials, Vol. 23; 2009, pp 411422. 
[15] Borri A, Corradi M, Grazini A. A method for flexural reinforcement of old wood beams with CFRP materials. Composites Part B: Engineering, Vol. 36; 2005, p.143-153.

[16] Kliger R, Johansson M, Crocetti R. Strengthening timber with CFRP or steel plates - short and long-term performance. In: Proceedings of World Conference on Timber Engineering, Miyazaki, Japan, 2008.

[17] Nowak TP, Jasienko J, Czepizak D. Experimental tests and numerical analysis of historic bent timber elements reinforced with CFRP strips. Journal of Construction and Building Materials, Vol. 40, 2013, p. 197-206.

[18] Plevis N, Triantafillou TC. FRP-reinforced wood as a structural material. Journal of Material Civil Engineering (43); 1992, p. 300-317.

[19] Triantafillou TC, Deskovic N. Prestressed FRP sheets as external reinforcement of wood members. Journal of Structures Eng. 118(5), 1992, p. 1270-1284.

[20] Yeboah D, Taylor SE, McPolin D, Gilfillan R. Pull-out behaviour of axially loaded Basalt Fibre Reinforced Polymer (BFRP) rods bonded perpendicular to the grain of glulam elements. Journal of Construction and Building Materials, Elsevier; 2013, p. 962-969.

[21] Taylor S, Robinson D, Sonebi M. Basalt-fibre-reinforced polymer reinforcement. Journal of Concrete, Vol. 45, No. 4, 2011. p. 47-51.

[22] Davis G. 1997. Performance of adhesives systems for structural timbers. International Journal of Adhesion and Adhesives, Vol. 17, No. 3; 1997, p. 247-255.

[23] Kangas J. Joints of glulam structures based on glued-in ribbed steel. VTT Publications, 196, 1994, Espoo.

[24] Williams CJ. The Effect of Moisture Absorption on Room Temperature Mechanical Properties of Reinforced Polymer Composites. Research and Development Report, Ship Materials Engineering Department, David Taylor Research Center, Report DTRC-SME-91/35, 1991.

[25] Bank LC, Gentry TR, Barkatt A. Accelerated Test Methods to Determine the Long Term Behavior of FRP. Composite Structures: Environmental Effects. Journal of Reinforced Plastics and Composites, Vol. 14, 1995, p. 559-587.

[26] Heshmati M. Hygrothermal Durability of Adhesively Bonded FRP/Steel Joints Department of Civil And Environmental Engineering Division of Structural Engineering Steel and Timber Structures, Chalmers University of Technology Gothenburg, Sweden. 2015.

[27] Harte AM, Raftery GM, Rodd PD. 2009. Bond quality at the FRP-wood interface using woodlaminating adhesives. Journal of Adhesion and Adhesives 29; 2009, pp 101-110.

[28] Surathi P, Karbhari V. Hygrothermal. Effects on durability and moisture kinetics of fiberreinforced polymer composites. Structural systems research project, 2006.

[29] Chu W, Karbhari VM. Effect of Water Sorption on Performance of Pultruded EGlass/ Vinylester Composites. Journal of Materials Civil Engineering; 2005, p. 63-71.

[30] Karbhari V, Chin J. Durability gap analysis for fiber-reinforced polymer composites in civil infrastructure. Journal of Composites for Construction; 2003, p. 238-247.

[31] Kumar SB, Sridhar I, Sivashanker S. Influence of humid environment on the performance of high strength structural carbon fiber composites. Material Science Engineering A 498 (1); 2008, p. 174-178. 
[32] Wang MC, Zhang ZG, Li Y, Li M, Sun ZJ. Chemical durability and mechanical properties of alkali-proof basalt fiber and its reinforced epoxy composites. Journal of Reinforced Plastics and Composites, Vol. 27; 2008, p. 393-407.

[33] Wheeler AS, Hutchinson AR. Resin repairs to timber structures. International Journal of Adhesion and Adhesives (18); 1998, pp 1-13.

[34] Broughton J. G., Hutchinson A. R. Adhesive systems for structural connections in timber. Int. Journal of Adhesives \& Adhesion, 21, 2001, p. 177-186.

[35] Guant DJ. 1998. Joints in glulam using groups of epoxy grouted steel bars plus an alternative to epoxy bonding. Proc., of the $5^{\text {th }}$ World Conf. on Timber Engineering, Montreux, Switzerland, Vol. 1; 1998, p. 281- 288

[36] Gustafsson PJ, Serrano E, Aicher S, Johansson CJ. A strength design equation for glued-in rods. Proceedings of the international RILEM symposium on joints in timber structures, Stuttgart, Germany, 2001.

[37] Serrano E. Glued-in rods for timber structures-an experimental study of softening behaviour. Journal of Materials and Structures 34; 2001, p 228-234.

[38] Harvey K, Ansell MP, Alexandre N, Mettem CJ, Bainbridge RJ. Bonded-in pultrusions for moment-resisting timber connections. Proceedings of $33^{\text {rd }}$ Conference of CIB-W18, Delft, The Netherlands; 2000.

[39] Windmann R, Steiger R, Gehri E. Pull-out of axially loaded steel rods bonded in glulam perpendicular to the grain. Journal of Materials and structures 40; 2007 p. 827 - 838.

[40] Gardelle V, Morlier P. Geometric parameters which affect the short term resistance of an axially loaded glued-in rod. Journal of Materials and Structures 40; 2007, pp 127-138.

[41] Bernasconi A. Behaviour of axially loaded glued-in rods - requirements and resistance, especially for spruce timber perpendicular to the grain direction. CIB-W18, Timber Structures, Italy, 2001.

[42] Yeboah D. Rigid Connections in Structural Timber Assemblies. PhD Thesis. Queen’s University Belfast; 2012.

[43] Bainbridge RJ, Mettem CJ, Ansell MP. An overview of research to assess fatigue performance of bonded-in rods for timber structures using three adhesive types, Proc. Cost Action E8 Workshop: Damage in wood: Mechanical performance of wood and wood products, Bordeaux; 1999.

[44] Gehri E. Ductile behaviour and group effect of glued-in steel rods. Proceedings of the international RILEM symposium on joints in timber structures, Stuttgart, Germany; 2001.

[45] Cosenza E, Manfredi G, Realfonzo R. Behaviour and modeling of bond of FRP rebars to concrete. Journal of Composites for Construction, 1997, p. 41-51.

[46] Deng JX, Buchanan AH, Moss PJ. Glued Bolts in Glulam-An Analysis of Stress Distribution. Proceedings, Fifth World Conference on Timber Engineering, Montreux, Switzerland. Vol 2; 1998, p. 206-213.

[47] Del Senno M, Piazza M, Tomasi R. Axial glued-in steel timber joints-experimental and numerical analysis. Holz als Roh- und Werkstoff, 62; 2004, p.137-146.

[48] BS ENV: 1995-2. European Committee for Standardization CEN Eurocode 5—design of timber structures-Part 2: Bridges, CEN, Brussels, 1997.

[49] De Velde VK, Kiekens P, Van Langenhove L. Basalt fibres as reinforcement for composites. Dept. of Textiles, Ghent University, Belgium; 2003.

[50] Bengtsson C, Johansson CJ. GIROD-Glued in rods for timber structures. SP Report 2002:26. SP Swedish National Testing and Research Institute; 2001. 
[51] Stumes P. Testing the efficiency of wood epoxy reinforcement systems. Association for Preservation Technology, Vol. 7, No. 3; 1975, p. 2-35.

[52] Aicher S, Wolf M, Hofflin L. Influenced of specimen geometry on stress distributions in pull-out tests of glued-in steel rods in wood. Otto-Graf Journal, 9, FMPA, Stuttgart, Germany; 1998.

[53] Majumder M, Gangopadhyay TK, Chakraborty AK, Dasgupta K, Bhattacharya DK. Fibre Bragg gratings in structural health monitoring-Present status and applications. Journal of Sensors and Actuation A - Physical Vol. 147 (1); 2008, pp 150-164.

[54] Plecnik JM, Iding R, Cunningham JD, Bresler B. 1980. Temperature effects on epoxy adhesives. J Struct Div-ASCE 106(1); 1980 p. 99-113.

[55] Gaozhi X, Honglei G, Nezih M, Jianping Y. Fiber Optic Sensors for Structural Health Monitoring of Air Platforms. Journal of Sensors and Actuation, Vol. 11; 2011, p. 3687-3705

[56] BS EN: 26891. Timber structures. Joints made with mechanical fasteners. General principles for the determination of strength and deformation characteristics, 1991.

[57] Yeboah D, Taylor SE, McPolin D, Gilfillan R. Pull-out behaviour of axially loaded Basalt Fibre Reinforced Polymer (BFRP) rods bonded parallel to the grain of glulam elements. The Structural Engineer, Vol. 90 (5); 2012.

\section{Bibliograpphy}

Rotafix Ltd, Rotafix House, Hennoyadd Road, Abercraf, Swansea, UNITED KINGDOM, SA9 1UR 